\title{
LÍNGUA MATERNA E ESTRANGEIRIDADE
}

\author{
Maria Rita Salzano Moraes*
}

\begin{abstract}
Resumo
A partir do relato de dois casos da literatura psicanalítica, proponho aos meus pares uma reflexão que aborda a diferença "natural" que estabelecemos como fronteira entre o familiar e o estrangeiro e que, por consequência, os coloca em lados opostos ou mesmo antagônicos. A ilustração vem interrogar os estatutos de familiar, atribuído à língua materna, e de estranho, atribuído à língua estrangeira. A concepçáo de sujeito que adotamos nos permite tomar, na representação do estranho, o elemento organizador, e não diferenciador, nessa relação entre línguas. É através dessa representação que se dá a passagem entre elas.
\end{abstract}

PalaVras-ChaVE: Língua materna, língua estrangeira, inconsciente, estranho.

\section{Mother-tongue and strangeness}

\section{Abstract}

Starting with the report of two cases from the psychoanalytical literature, I propose to my peers a reflection that involves the "natural" difference established as a frontier between the familiar and the stranger and, as a consequence, puts them in opposite or even conflictive sides. The illustration comes to interrogate the familiar status ascribed to the mothertongue and the queer status assigned to the foreign language. The conception of subject adopted allows us to take the representation of the stranger itself as an organizing and not discriminating element in the relationship between languages. It is through this representation that the passage takes place between them.

KEY WORDS: Mother tongue, foreign language, unconscious, uncanny.

É quase impossível para nós que ensinamos língua estrangeira conceber a idéia de que aquilo que pensamos ser nossa língua materna possa conter qualquer elemento de estrangeiridade. Esse elemento é mais provável de ser encontrado, segundo nossa crença, na língua estrangeira. "Materno" seria, então, aquilo que nos é intimamente familiar.

* Professora do Departamento de Linguística Aplicada do Instituto de Estudos da Linguagem (IEL) da Universidade Estadual de Campinas (Unicamp). Doutora em Linguística pela Unicamp. Membro da Escola de Psicanálise de Campinas - SP. E-mail: mrita@unicamp.br. 
A partir de dois casos que relatarei a seguir, proponho aos meus pares uma reflexão que aborda a diferença "natural" que estabelecemos como fronteira entre o familiar e o estrangeiro e que, por consequência, os coloca em lados opostos ou mesmo antagônicos.

No entanto, se privilegiamos esses dois casos é porque consideramos, com Freud e Lacan, que o sujeito é constituído por linguagem e, nesse caso, a ilustração vem interrogar os estatutos de familiar atribuído à língua materna e de estranho atribuído à língua estrangeira. A concepção de sujeito que adotamos nos permite tomar, na representação do estranho, o elemento organizador, e não diferenciador, nessa relação entre línguas. É através dessa representação que se dá a passagem entre línguas. A inclusão do sujeito, nessa perspectiva, permite que o estranho não as diferencie, mas que as coloque, como diz Freud ([1891] 1977), nas mesmas áreas, que as tome primeiramente enquanto elementos de linguagem, de maneira que se possa entender a relação com a língua estrangeira como uma leitura que o sujeito realiza a partir da língua materna.

\section{O ESTRANHo Na Língua Materna}

O primeiro caso é o de Anna O., uma paciente de Freud (Estudos sobre a histeria, [1893] 1996), que julgo pertinente neste trabalho, uma vez que Freud elenca entre seus sintomas o esquecimento da língua materna, trocada, durante longo período, pela língua inglesa.

Ao relatar o caso dessa paciente, Freud nos informa sobre o momento que deu origem ao sintoma: a paciente Anna O. encontrava-se sentada à cabeceira do leito de seu pai enfermo quando colocou o braço direito sobre o espaldar da cadeira e adormeceu por cansaço, entrando, em seguida, em um estado alucinatório. Viu, como se saísse da parede, uma cobra negra que se aproximava do doente para mordê-lo. Tentou afugentar a cobra, mas não pôde fazê-lo, pois seu braço encontrava-se dormente e insensível. Acrescenta-se a isso o fato de que, durante a alucinaçáo, ao olhar para seus dedos, estes haviam se transformado em pequenas cobras, cujas cabeças e unhas eram caveiras. Quando a cobra desapareceu, "ela tentou rezar, mas não conseguiu encontrar as palavras em nenhum idioma, até que, lembrando-se de um poema infantil (ou oração) em inglês, pôde pensar e rezar nessa língua” (idem, p. 40 e 73, grifo nosso). 
Segundo Freud, o estado (afeto) emocional de angústia, determinado pelo impacto da conjunção entre a alucinação e o adormecimento do braço, teve como consequência uma inibição da fala, que encontrou uma descarga fortuita nos versos do poema/oração infantil em língua inglesa (idem, p. 40, grifo nosso).

Passemos agora à questão da representação e do afeto. Freud havia dito que o afeto de angústia determinado pelo impacto da alucinaçáo e somado ao adormecimento do braço não pôde ligar-se a uma representação adequada na língua alemã para sua descarga, encontrando, possivelmente, outra representação da fala em língua inglesa com certa carga emocional por ser uma oração ou poema. Mas, apesar de encontrar a descarga fortuita na língua inglesa, seu braço, após o incidente, permaneceu paralisado.

De acordo com o que compreendemos da leitura de Estudos sobre Histeria (Freud, op. cit.), a paralisia é interpretada por Freud como uma lesão que não depende da anatomia do sistema nervoso, mas se constrói imaginária e simbolicamente. Uma representação particular e intolerável, por ser altamente investida de afeto, deixa de integrar o conjunto das representaçôes e, ao ligar-se à outra representação, converte-se em sintoma. A transformação posterior da representação intolerável (o temor de ver seu pai doente mordido pela cobra e sua paralisia) em sintoma (falar inglês e a paralisia do braço) está referida à própria ligação motora entre as duas representaçóes (a fala na língua materna e a paralisia). $\mathrm{O}$ acréscimo dessa outra representação (falar inglês) é decisivo porque ela escapa ao saber. É por isso que Freud diz que o trauma se transforma em sintoma quando existe uma relação simbólica ligando aquilo que ele evoca com outra representação, sem que o Eu dela tenha notícias ou possa intervir para impedi-la.

Essa outra representação comporta um excesso de afeto do qual o Eu não pode se libertar, portanto, subtrai do registro do Imaginário um de seus suportes simbólicos, o qual assume esse excesso de afeto que pertence à outra representação, dando ao sintoma seu peso de real.

Segue-se que, após esse acontecimento, a paciente apresentou constantes contraturas e anestesias no mesmo braço e, paralelamente ao desenvolvimento das contraturas, surgiu uma profunda desorganização funcional da fala. A princípio, sentia dificuldade em encontrar as palavras. Depois, perdeu o domínio da gramática e da sintaxe, pois não mais conjugava verbos e acabou por empregar apenas os infinitivos, formados incorretamente 
a partir dos particípios passados, além de omitir os artigos definidos e indefinidos. Com o passar do tempo, ficou quase desprovida de palavras. Juntava-as penosamente a partir de quatro ou cinco idiomas e sua fala tornou-se quase ininteligível (Freud, idem, p. 60).

Esse fato remete-nos para o que Freud ([1891] 1977) traz em A Interpretação das Afasias sobre a questão da parafasia, distúrbio que evidencia os diferentes níveis funcionais da estruturação das funções da linguagem. Freud extrai sua hipótese sobre a estruturação das funções da linguagem dos casos patológicos de lesão orgânica na área da linguagem. No caso de lesão, aquilo que foi inscrito mais recentemente e permanece mais eficiente é o que se perde primeiro. A língua materna seria, portanto, a última a sofrer os danos de uma lesão.

No caso da paciente de Freud não houve lesão. No entanto, só passou a falar o inglês após apresentar uma espécie de afasia na língua materna. Essa disfunção da fala na língua materna aconteceu ao mesmo tempo em que começou a apresentar contraturas, anestesias e paresias no braço. A parafasia se deu gradativamente, pois foi perdendo aquilo que Freud chama de funçôes da linguagem, repetindo uma situação que se apresenta normalmente durante a inscrição dessas funçóes, até, finalmente, emudecer por completo.

A representação intolerável foi esquecida, assim como foram se perdendo as funções da fala na língua materna, desaparecendo também a representação das duas imagens motoras, a da fala na própria língua e a do movimento. Acrescenta-se a representaçáo da língua estrangeira que veio em seu socorro no momento de aflição.

No relato de Freud ([1891] 1977, p. 61), o fenômeno das contraturas associou-se de tal maneira à questáo da fala que, posteriormente, quando a paralisia regrediu, a paciente passou ao sintoma: "passou a falar apenas inglês - só que, aparentemente, sem saber que o estava fazendo (pois discutia com a enfermeira, que não conseguia entendê-la)". Meses depois, Freud consegue convencê-la de que ela estava falando inglês.

Podemos nos perguntar, agora, a respeito da familiaridade com que é tratada a língua estrangeira nesse caso. Parece-nos que esta, pela maneira como o caso é apresentado, vem no lugar do estranhamento na língua materna. Devido à condição de alteridade da própria língua materna, que se impóe como uma representação absolutamente estranha, a língua estrangeira se apresenta como a mais familiar. 


\section{O FAMILIAR NA LÍNGUA ESTRANGEIRA}

O segundo caso que gostaria de relatar vem da leitura que Fontaine (1987, p. 73-101) faz da obra de Wolfson. Autor de Le schizo et les langues (1970), Wolfson, cuja língua materna é o inglês, escreve em francês, e nos interessa destacar e extrair as consequências das ações que empreende a partir de sua relaçáo com sua língua materna. Seus escritos em francês possuem uma razão comum: sua luta contra a perseguição da língua materna, contra a qual ele se empenha em um trabalho de desarticulação.

Nesse livro, Wolfson recebe e reage às sonoridades de sua língua materna (e particularmente à voz de sua mãe), pois esses sons produzem em sua cabeça um eco intolerável e próximo da dor, que ele tenta suspender. Para isso, náo pode fazer nada menos do que destruir, sistematicamente, todas as palavras da língua inglesa, isto é, desarticular todos os vocábulos dessa língua, fonema por fonema.

Sua relação com a língua inglesa testemunha parte importante do processo que envolve os efeitos da percepção da imagem sonora e da imagem motora da fala, ou seja, a simultaneidade com que a fala afeta o corpo diretamente, em um unissono quase exato da vibração das cordas vocais da mãe às vibrações da membrana do tímpano do filho:

Aliás, durante esse tempo, a mãe do estudante alienado o tinha seguido e chegara a seu lado, quando dizia, de vez em quando, alguma coisa de bem inútil - ao menos o jovem assim pensava - e naturalmente em inglês, e parecia se tomar de uma espécie de alegria macabra pela boa oportunidade de injetar de algum modo as palavras que saíam de sua boca nas orelhas de seu filho, sua única criança - ou, como ela lhe dizia de tempos em tempos -, de sua única posse, parecendo tão feliz por fazer vibrar o tímpano dessa única posse e, por conseqüência, a membrana do ouvido médio da dita possessão, de seu filho, em uníssono quase perfeito com suas cordas vocais, apesar de ele também as ter. (Fontaine, 1987, p. 78)

Mas não é somente a voz, enquanto tal, que faz com que ele falhe em se desvencilhar desse lugar. Wolfson percebe uma intenção subjacente, um tom de triunfo na voz da mãe. Se Wolfson se esforça por distorcer os sons do inglês, é para mudar a tonalidade, para agir sobre o tom de má vontade, sobre o desejo de lesá-lo (idem, p. 79). Apesar de todas as alegaçôes maternas de boas intenções e de ligação com seu filho, é sobretudo 
a conduta verbal [que pode também ser o conduto auditivo] que fornece a maior prova de uma indiferença fundamental, ou até mesmo de uma verdadeira antipatia por ele (idem).

Parece não ser, portanto, o sentido das palavras, mas os sons das palavras que o enredam nesse mal-estar, algo que, anterior a elas, as acompanha, um afeto que se impóe em bloco através da tonalidade da voz da mãe. A voz materna, o uso que a mãe faz da língua inglesa e esta, por extensão, enquanto utilizada por toda uma comunidade da qual sua mãe é parte, todas essas vozes reverberam no seu cérebro e fazem com que Wolfson, para neutralizar esse desejo de lesá-lo e para agir sobre os efeitos dessa voz, faça suas operações sobre a língua.

Wolfson procura, então, nos vocábulos escritos ou falados dessa língua ou de outras línguas, o apoio necessário para contrapor o uso que sua mãe faz do inglês. Esse apoio ele encontra pela via da escrita, no esqueleto consonantal da lingua, pois ele diz que as vogais náo lhe importam e que as consoantes são mais estáveis, permitindo o despedaçamento mais eficiente de um vocábulo. Isso o autoriza a identificar as correspondências consonânticas com o que ele chama de congêneres nas outras línguas. Seu objetivo em fazer desaparecer um vocábulo é alcançado, então, quando uma relação termo a termo for estabelecida com um outro, entre as cinco línguas de que o autor dispóe.

Queremos destacar aqui que Wolfson procura resolver com o escrito esse mal-estar com relação à tonalidade da voz, como se o escrito o remetesse a uma espécie de origem, ao momento mesmo da inscrição das marcas da linguagem no corpo. Sua estratégia consiste em procurar, em outras línguas, equivalências consonânticas, o que faz, opondo ao caractere purificado da alucinação na própria língua, as conversóes homofônicas tornadas instantâneas. Isso tem como efeito fazer cessar a reverberação dolorosa, mas deixa intacta a instância persecutória da voz. A voz apenas presentifica o mal-estar para Wolfson. Ele procura encontrar, no mais real/ puro da escrita, um ponto de conversão homofônica com outras línguas, para fazer escoar por aí o afeto desagradável que o tolhe.

Com esses jogos linguísticos, baseados nas semelhanças de sentido e de som entre as palavras inglesas e as palavras estrangeiras, a língua inglesa, destruída pouco a pouco, se torna cada vez mais suportável:

Não conseguir sentir sua língua materna como uma entidade [...] mas, em compensaçáo, de poder senti-la bem diferentemente, como alguma coisa de além, como exótica, como uma mistura, um potpourri de vários idiomas. (Fontaine, idem, p. 83) 
Para se tornar suportável, sua língua materna deve se abrir às línguas estrangeiras para, com isso, perder o impacto da onipotência em que se transformou pela tonalidade da voz da mãe. Seu desejo, ao procurar correspondências entre os sons das línguas, é alargar suas fronteiras e escapar à perseguição. Wolfson toma a sonoridade da língua materna em um momento anterior ao sentido e a usa como o veículo do afeto náo dito dirigido a ele. $\mathrm{O}$ som do afeto não dito causa seu trabalho de desconstruçáo dessa língua. Wolfson procura, ainda, na marca mais real dessa inscrição, a maneira de reescrever esse afeto não dito pela mãe. Ao desmontar a língua inglesa fonema por fonema para reescrevê-la em outras línguas, ele nos revela os mecanismos pelos quais os sons dos afetos de sua língua materna se impuseram a ele de maneira literal.

A palavra, para Wolfson, fascina pelo oposto do sentido, por aquilo que ela traz de sinal, de marca, de letra. Sua operação de destruição dos sons da língua materna com a escrita revela uma fixaçáo, em um dos tempos de estruturação, das funçóes da linguagem, que, segundo Freud ([1891] 1977, p. 60), compreende, em primeiro lugar, o sensorial-acústico, depois o motor, mais adiante o visual e, por fim, o gráfico.

Parece-nos que, no caso de Wolfson, algo tornou inoperante a mediação da relação imaginária produzida pela linguagem, fazendo com que o som da língua materna retornasse para ele sem apoio no Simbólico, como um real persecutório. Essa perseguição não é da ordem da significação, pois Wolfson não se apressa em compreendê-la; ela tem seu motivo em um fato de escrita, em uma leitura específica daquilo que a voz da máe revela pelo não dito. Sua maneira de usar a língua para desarticulá-la com o apoio de outras línguas surpreende pela seriedade com que produz seu escrito sobre o caractere alucinado dessa língua materna, evidenciando algo que, da estrutura da linguagem, só se revela pelo escrito. Desarticula, no corpo consonantal da língua, aquilo que faz marca em seu próprio corpo.

\section{INCLUINDO O ESTRANHO}

Os casos relatados apontam para o tênue limite entre língua materna e língua estrangeira porque o estranho da língua materna se apresenta como o elemento organizador na relação entre as línguas. $\mathrm{O}$ limite entre as línguas é questionado por Wolfson a partir da visada das correspondências fundadas nas sonoridades das línguas. A língua materna se apresenta, nesse 
caso, como uma maneira singular de Wolfson se relacionar com a linguagem. Essa língua Wolfson a escuta pelo corpo, convocado pela sonoridade literal, como se ela estivesse à espera de uma leitura. O que Wolfson ouve dessa língua é um modo particular de inscrição da linguagem no corpo.

Os dois casos nos fazem constatar que toda relação com uma língua estrangeira passa, necessariamente, pela relação estranho-familiar na língua materna. O que se destaca é o movimento do estranho fazendo deslizar o familiar de outro texto. Para Anna O., o inglês vai recobrindo o alemão, para re-calcar esse estranho que irrompe na língua alemã. O estranho, nesse caso, movimenta, isto é, causa o desejo, causa o familiar, porque o estranhofamiliar encontra-se ainda no campo do sentido, no campo representacional. Anna O. não deseja o impossível, deseja, porque é impossível.

No caso de Wolfson, as outras línguas entram para de-fendê-lo da língua inglesa. Esta só lhe aparece como estranho, uma vez que não importa, para Wolfson, o campo do sentido. Assim, as outras línguas entram para movimentar o estranho da língua materna que invade como uma língua estrangeira. $\mathrm{O}$ estranho não se apresenta aqui como aquele que póe em movimento e, portanto, náo pode causar o familiar. O que restou a Wolfson de familiar é de outra ordem, não se encontra no campo representacional, apresenta-se como dor, no corpo. Se o estranho não pode causar o desejo, Wolfson busca o impossível: com o literal da linguagem, ou seja, nas letras das línguas estrangeiras, defender-se da perseguição e dissolver a tonalidade dessa língua materna, cuja ressonância o capturou no corpo.

\section{REFERÊNCIAS}

FONTAINE, A. Pour une lecture de Louis Wolfson. Littoral, n. 23/24, 1987.

FREUD, S. [1891]. A interpretação das afasias. Trad. de António Pinto Ribeiro. Lisboa: Ediçōes 70, 1977.

- [1893-5]. Estudos sobre histeria. Edição Standard Brasileira das Obras Psicológicas Completas de Sigmund Freud. v. II. Rio de Janeiro: Imago, 1996.

Recebido em: 06 nov. 2008 Aceito em: 20 fev. 2009 


\title{
O ENSINO E A APRENDIZAGEM DE LÍNgUa ESTRANGEIRA: ALGUMAS QUESTÓES SOBRE O CORPO
}

\author{
Silvana Matias Freire* \\ Newton Murce ${ }^{* *}$
}

E acontece o seguinte: quando estranho a pintura, ai é que é pintura, e quando estranho a palavra, aí é que ela alcança o sentido, e quando estranho a vida, aí é que começa a vida.

Clarice Lispector

\section{Resumo}

O objetivo deste texto é trazer algumas questóes sobre o processo de ensino e aprendizagem de línguas estrangeiras, levando-se em consideração uma concepção de corpo fundamentada na psicanálise, que o concebe como efeito de linguagem ou corpo pulsional, corpolinguagem.

PalaVras-Chave: Ensino, língua estrangeira, corpo, psicanálise.

\section{Teaching and learning foreign languages: some questions on the body}

\section{AbStract}

The aim of this text is to present some questions about the process of teaching and learning foreign languages, taking into account a conception of body based on psychoanalysis, according to which the body is conceived as effect of language or pulsional body, body language.

KEY WORDS: Teaching, foreign language, body, psychoanalysis.

O objetivo deste texto é trazer algumas questôes sobre o ensino e a aprendizagem de línguas estrangeiras, especialmente no que concerne a uma concepção de corpo fundamentada na psicanálise, que o concebe como corpo pulsional ou corpolinguagem, corpo efeito de linguagem.

As inquietaçóes que levaram à escrita do trabalho baseiam-se nas observaçóes e experiências de seus autores, como professores de língua estrangeira e também como pesquisadores da área.

\footnotetext{
Professora de Língua Francesa no Centro de Ensino e Pesquisa Aplicada à Educação (Cepae/UFG). Doutora em Linguística pela Unicamp. E-mail: silvfreire@ig.com.br.

** Professor de Língua Inglesa do Cepae/UFG. Doutor em Linguística pela Unicamp. E-mail: newtonmurce@yahoo.com.br.
} 
Dentre essas observaçôes, experiências e pesquisas, pode-se destacar, por exemplo, a frustração, muito comum entre professores, em relação a uma expectativa não alcançada por parte de seus alunos, o que não se restringe, evidentemente, às aulas de língua estrangeira (LE), mas à educação em geral. Outro exemplo, que diz respeito aos livros didáticos para o ensino de LE, é que não se percebe nenhuma referência ao corpo que vá além do que este comporta do registro do imaginário, isto é, do que concerne ao campo do sentido. O corpo é basicamente um corpo utilitário, assim como a língua é meramente um "instrumento de comunicação". Daí a LE vai "servir para" o aluno aprender "como" comprar um bilhete numa estação, como pedir comida em um restaurante, como orientar-se dentro de uma cidade desconhecida etc. Os textos também muitas vezes são utilizados como pré-textos "para" alguma coisa, antes de serem considerados por eles mesmos, como fruição, por exemplo. Claro que esses conteúdos também são importantes, mas não são tudo. Aprender uma LE é muito mais complexo - ou muito simples, para alguns -, é verdade, mas, de qualquer modo, não é sem consequências para o corpo.

De uma maneira geral, há uma grande preocupação, tanto nos livros didáticos quanto na própria sala de aula, com o que deve haver de uma (im)possível "garantia" de comunicação, como se a língua fosse transparente, completa, sem equívoco, como se não houvesse corpo desejante e, portanto, a falta constitutiva do sujeito, a incompletude, como se náo houvesse singularidade, como se não houvesse sofrimento ao aprender uma nova língua. A título de exemplos do dia-a-dia escolar, perguntamos: por que a produção de um dado som é impossível ou tão incômoda para um estudante e não para outro (o "th" inglês, por exemplo)?; por que, para alguns, ouvir alguém falando espanhol, que parece tão familiar ao português, pode ser tão incômodo, angustiante?; por que o francês pode remeter ao belo - "francês é tão bonito", comumente ouvimos esse comentário -, ou a algo prazeroso ao ouvido?; por que, de uma hora para outra, um aluno de Ensino Fundamental póe-se a ler compulsivamente livros em francês sem ser exigido pela professora?

Enfim, são perguntas e observaçóes como essas que nos levam, auxiliados por alguns trabalhos significativos já realizados na área (Revuz, 1998; Moraes, 1999; Veras, 2008), a trazer algumas questóes sobre o corpo que possam conduzir à reflexão. 


\section{SOBRE EDUCAÇÃO E PSICANÁLISE}

Há trabalhos recentes que tratam do tema educação e psicanálise, tais como Azenha (2007), De Lemos (2007), Veras (2008), Vorcaro (2008), Lajonquière (1999), Camargo (2006), Voltolini (2007).

No entanto, é importante retornar ao autor que fundou tal discussão para melhor compreender o modo como as pesquisas recentes tratam do tema e, com essa compreensão, oferecer possíveis contribuiçôes. Em 1925, Freud aborda a questão das aplicaçóes da psicanálise na educação e mostra muita cautela em fazer tal aproximação, afirmando que "o trabalho da educação é algo sui generis: não deve ser confundido com a influência psicanalítica e não pode ser substituído por ela [...]. Tal substituição não só é impossível em fundamentos práticos, como também deve ser desaconselhada por razóes teóricas" (Freud, 1925, p. 308).

Freud alerta ainda que se a psicanálise pode propiciar algum benefício à educaçáo, isso ocorre se o educador se submete a uma análise e a experimenta em si mesmo, pois essa experiência lhe daria uma possibilidade de maior insight sobre o infantil.

A concepção freudiana de educação escolar não se distingue da educação da criança pelos pais, pois ambas visam à transmissão cultural impondo a renúncia às pulsóes. Nas palavras da psicanalista De Lemos (2007, p. 84): "a concepção freudiana da educação impressiona por sua total desconsideração pelos ideais pedagógicos: trata-se de fazer com que a criança aprenda a controlar suas pulsóes e ponto final!".

Isso não significa desmerecer o empreendimento educativo, mas mostrar que a educação tem como missão inarredável inibir, proibir, suprimir e direcionar as pulsôes. A não realização dessa missão implica uma renúncia ao ato educativo. As aplicaçóes da psicanálise no campo da educação apontam para essa renúncia (ou para a resistência à psicanálise).

A função recalcante e inibidora da educação é, por outro lado, uma condiçâao propícia para despertar desejo no sujeito, ou seja, sem a operação de interdição das pulsôes, o desejo (de conhecer) não comparece. Freud idealiza, porém, um ponto 'ótimo' ao qual a educação deve atingir:

A educação tem de escolher seu caminho entre o Sila da náo-interferência e o Caríbdis da frustração [...]. Deve-se descobrir um ponto ótimo que possibilite à educaçáo atingir o máximo com o mínimo de dano. Será, 
76 Revista Solta a Voz, v. 20, n. 1

portanto, uma questão de decidir quanto proibir, em que hora e por que meios (Freud, 1932, p. 147).

Eis o desafio com o qual o professor se defronta em seu cotidiano. Como instaurar o desejo de aprender no aluno - desejo inexistente na criança, segundo Freud - a partir da operação de interdição? De Lemos (2007, p. 87) indica que a condição para engajar o aluno numa via desejante não está no desejo de educar do professor, está no fato de que o desejo do professor se dirija para Outro lugar: "É assim quando, por exemplo, o desejo do professor é causado mais pela Matemática do que pela necessidade de reencontrar no aluno os sinais de confirmação de que sua mensagem foi recebida sem deformaçóes" (De Lemos, 2007, p. 87).

Uma alternativa que evitaria o recalcamento ou a inibição das pulsôes é o desvio destas pela via da sublimação. Daí lembrarmos a importância de uma experiência com a literatura, a música, a pintura, o teatro, por exemplo, como meios de os alunos entrarem em contato com a produção humana que resulta do desvio das pulsôes. Contato que se dá corporalmente, isto é, como olhar, voz, escuta, movimento.

\section{O QUE SE MOBILIZA QUANDO SE APRENDE UMA LE}

Há significativos trabalhos sobre a complexidade do que está envolvido nas dicotomias familiar/estrangeiro (Freud, 1919), língua materna/ língua estrangeira (Moraes, 1999; Veras, 2008), mesmo nos textos presentes neste volume (Barichello, Moraes), mas para o momento, o texto de Revuz (1998) é bastante esclarecedor.

Para ela, a aprendizagem de LE vem questionar a relação que está instaurada entre o sujeito e sua língua. A pesquisadora (1998, p. 216-217) aborda a complexidade e a dificuldade de se aprender LE, que "solicita o sujeito, seu modo de relacionar-se com os outros e com o mundo: prática corporal, ela póe em jogo todo o aparelho fonador". Essa aprendizagem mobiliza dimensôes da pessoa que geralmente não colaboram, nem mesmo convivem, em harmonia. O sujeito põe a serviço da expressão de seu eu um vaivém que requer muita flexibilidade psíquica entre um trabalho de corpo sobre os ritmos, os sons, as curvas entoacionais, e um trabalho de análise e de memorização das estruturas linguísticas: "muitos dos insucessos podem ser analisados como uma incapacidade de ligar essas 
três dimensôes: afirmação do $e \mathcal{U}$, trabalho do corpo, dimensão cognitiva" (Revuz, 1998, p. 217).

Aprender LE é complexo porque solicita, ao mesmo tempo, nossa relaçáo com o saber, com o corpo e com nós mesmos como sujeitos falantes. Além disso, solicita as bases de nossa estruturaçáo psíquica e, com elas, aquilo que é, ao mesmo tempo, o instrumento e a matéria dessa estruturação, ou seja, a linguagem, a língua chamada materna. Portanto, "toda tentativa para aprender uma outra língua vem perturbar, questionar, modificar aquilo que está inscrito em nós com as palavras dessa primeira língua” (Revuz, 1998, p. 217). Antes de ser objeto de conhecimento, a língua é o material fundador de nosso psiquismo e de nossa vida relacional, daí que a língua não é mero instrumento de comunicação. A língua causa sujeito. Somos efeito de linguagem. Da estreita "relação" entre corpo e LE, a autora (1998, p. 219) afirma:

A descoberta das palavras, das significaçóes lingüísticas é indissociável da experiência da relação com o outro e das significações libidinais que se inscrevem nela. A voz, as palavras da mãe são fontes de prazer ou de desprazer; elas têm, além disso, o poder de interferir nas outras sensaçóes (visão, tato, paladar) reforçando ou anulando os sentimentos de prazer ou de desgosto que são ligados a elas.

O sofrimento que constitui uma experiência de aprendizagem é abordado por Revuz (1998, p. 230) nos seguintes termos:

Mais que em problemas técnicos, a aprendizagem de LEs esbarra na dificuldade que há para cada um de nós, não somente de aceitar a diferença mas de explorá-la, de fazê-la sua, admitindo a possibilidade de despertar os jogos complexos de sua própria diferença interna, da não coincidência de si consigo, de si com os outros, de aquilo que se diz com aquilo que se desejaria dizer.

Sobre os obstáculos aos aprendizes, que podem se manifestar por meio de dificuldades de jogar de modo diferente com a música, com a acentuação, sons, ritmos ou sobre os sucessos, isto é, para aqueles que se apropriam com facilidade da música outra, do significante, a autora (1998, p. 220) aponta a seguinte hipótese:

isso (fracasso ou sucesso) constitui indício de alguma coisa do funcionamento psíquico do sujeito. Ainda que ponderando que seria desatino 
emitir interpretaçóes sobre as dificuldades dos aprendizes, pode-se ajudar a superá-las, remetendo-as não a um estado de fato ("tenho a memória ruim", "não posso pronunciar este som", "não compreendo gramática"), mas a "um sentido, a uma história singular com a língua. A cada um corresponde, em seguida, decifrar esse sentido, se assim o desejar".

Há uma frase de Revuz (1998, p. 227) que resume muito bem o que ela desenvolve ao longo de seu artigo e que para nós é especialmente significativa: "aprender uma língua é sempre, um pouco, tornar-se um outro".

A aprendizagem de uma língua estrangeira tem como referência a língua materna, no que elas se aproximam ou distanciam (sons e sentidos diferentes ou parecidos, mesma raiz etimológica). A língua materna, não sabemos dizer como foi que a aprendemos, parece-nos, quase sempre, que ela nunca foi aprendida: "Esse estar-já-aí da primeira língua é um dado ineludível, mas essa língua é tão onipresente na vida do sujeito, que se tem o sentimento de jamais tê-la aprendido, e o encontro com uma outra língua aparece efetivamente como uma experiência totalmente nova” (Revuz, 1998, p. 215).

Náo podemos dar o testemunho de como aprendemos a língua materna. Podemos, no entanto, supor como isso se deu. Podemos supor que, de início, a aquisição da língua materna não se dá 'naturalmente', mas é resultado de um ensino em que, se não se exige um local e hora marcados e conteúdos definidos como o que ocorre na escola, não prescinde de um esforço do lado do infans (não falante) e imposições de regras do lado do Outro. Nas palavras de Freud (1905, p. 122-123):

O período em que uma criança adquire o vocabulário da língua materna proporciona-lhe um óbvio prazer de 'experimentá-lo brincando com ele', segundo as palavras de Gross [p. 125]. Reúne as palavras, sem respeitar a condição de que elas façam sentido, a fim de obter delas um gratificante efeito de ritmo ou de rima. Pouco a pouco esse prazer vai lhe sendo proibido até que só restam permitidas as combinaçóes significativas de palavras.

Por outro lado, a língua estrangeira usualmente exige mediações pedagógicas e técnicas e se dá em um tempo em que o sujeito tem condiçôes simbólicas de verbalizar sua experiência de aprendizagem - dificuldades, dúvidas etc. No entanto, o fracasso é mais frequente.

Se há sofrimento, resistência, perda e ganho de prazer na aquisição da língua materna, podemos supor que o encontro com uma LE vai atualizar 
tais sentimentos no sujeito aprendiz: "Toda tentativa para aprender uma outra língua vem perturbar, questionar, modificar aquilo que está inscrito em nós com as palavras dessa primeira língua. Muito antes de ser objeto de conhecimento, a língua é o material fundador de nosso psiquismo e de nossa vida relacional" (Revuz, 1998, p. 217).

\section{Corpo e SENTIDO}

O que pode estar em jogo na aprendizagem de uma língua estrangeira é como o aprendiz lida com a rememoração de sua condição de infans, ou seja, de sua condiçấo de não falante que um dia ele teria sido. Nessa condição, o que a criança ouve é uma voz

plena de música, que introduz na criança o sopro criador de falantes, e a criança recebe de sua máe essas vibraçóes harmônicas, cintilantes, mutantes, da fala - acordossom [...]. Esse momento zero da chegada do sujeito é marcada pelo esquecimento, recoberto, apagado pela entrada do sujeito na linguagem (Veras, 2008, p. 117).

Essa fala não pode ainda ser recortada em sequências sonoras pelo sujeito, ou seja, em palavras que fazem sentido. Segundo Pommier (2004, p. 144), nos primeiros encontros com uma LE só se pode escutar a música

de uma língua estrangeira que não compreendemos, ouvimos primeiro um fonetismo que não percebemos mais em nossa língua, ocupados que estamos pela significação do que exprimimos. Escutando uma língua incompreensível, ouvimos sons tão estranhos quanto aqueles da primeira música, da qual perdemos a memória atribuindo às palavras um sentido. A língua estrangeira evoca este gozo perdido. Pela via da sonoridade, ela nos toca, nos desagrada ou, ao contrário, nos seduz. (tradução nossa)

A LE evoca no aprendiz aquele momento que Freud descreve: momento em que se brincava com os sons sem se preocupar em fazê-los significar. Mas, o que o som sem sentido implica? Implica que se náo temos o sentido para reter a nossa atenção, o que se coloca em primeiro plano é um corpo que profere sons. É na ausência de sentido que o corpo se faz presente, é o corpo que atua e se coloca em primeiro plano. Ao privilegiar o "como se diz" (forma), em detrimento de "o que se diz" (conteúdo), deixa- 
mos de lado o sentido: "O que fica em evidência, assumindo um primeiro plano, é o som da própria voz [...] e a performance (não a da retórica: num discurso em que o sentido não está excluído, o que se diz e como se diz não se separam) dos órgãos que se colocam em funcionamento nesta produção vocal" (Freire, 2007).

A experiência esquecida com os sons da língua materna é atualizada nas formas com que os sujeitos aprendizes lidam com a aprendizagem de LE. Reaçôes como rubor, suor, tremor, gagueira, hesitaçôes etc. são comuns em salas de aula de línguas estrangeiras, nos momentos como este: "o aluno que começa a aprender e tem dificuldade em pôr sua língua entre os dentes, porque aquilo que precisa articular não é um fonema de sua língua - ou seja, não serve para distinguir segmentos que façam sentido" (Veras, 2008, p. 116).

Momentos em que, desprovidos da máscara dos sentidos, o corpo fica exposto de forma constrangedora.

\section{Corpo REAL SIMBólico E IMAGINÁRIO}

No início do texto foi mencionado que o corpo que se concebe nos livros didáticos de LE é um corpo mais restrito ao registro do imaginário. Convém esclarecer no que consiste o corpo em psicanálise, corpo efeito de linguagem, corpo que é a um só tempo real, simbólico e imaginário. Isso é importante para podermos entender a complexidade que está envolvida no que Revuz chama de "tornar-se um pouco um outro".

De acordo com a psicanálise, o corpo não é o corpo puramente orgânico, natural, biológico, mas corpo efeito de linguagem. Conforme esclarece Garcia-Roza (1990), não se pretende, no entanto, dizer que o biológico não existe ou desconsiderar a representação imaginária do corpo biológico. O corpo psicanalítico, o corpo pulsional, não é a antítese do biológico, apenas diferente.

Além da dimensão do registro simbólico, o corpo está simultaneamente referido aos registros do imaginário e do real. Esta tripartiçáo estrutural constitui os três registros ou instâncias a partir das quais é possível apreender a experiência do sujeito. Lacan (1974/5) apresenta os três registros dentro da estrutura do nó borromeano, unidos por elos que não podem ser isolados, pois, uma vez desatado qualquer um, os outros se desligam simultaneamente. O nó borromeu possibilitou a Lacan demonstrar que, para que a estrutura se dê, é preciso pelo menos três elementos. 
Resumidamente, o simbólico (S) constitui o campo da linguagem ou do inconsciente estruturado como uma linguagem; o real (R) é o campo do impossível, do que estaria fora da linguagem, constitui o irrepresentável, o resto que sobra da entrada do sujeito na linguagem; o imaginário (I) é o campo da consistência, do sentido, da imagem especular. O real é efeito do simbólico e diz respeito ao campo da Coisa, que é a parte excluída do ser humano quando este, sem identidade, deixa-se representar pelo nome que vem do Outro. É um campo que está além do bem e do mal, campo do "pior", campo de força, de guerra, de gozo, campo do irrepresentável e do intangível. No entanto, campo que tem poder criativo. É por isso que Fingermann (2005) chama Beckett, Duras e Lispector de "passadores do pior" porque nos proporcionam encontros inauditos que nos capturam, deslumbram e mudam nossas vidas. $\mathrm{O}$ registro do real constitui a falta originária da estrutura, o impossível de ser simbolizado. Não é o que se chama de realidade, pois remete justamente ao que escapa a essa realidade, isto é, ao que é da ordem do traumático, do inassimilável, do irrepresentável, enfim, ao que não se inscreve no simbólico. Embora não se inscreva no simbólico, esse real produz efeitos no corpo.

Ao longo de seu ensino, Lacan dá maior ênfase ora para um, ora para outro registro. Teríamos, assim, por exemplo, uma direção que vai do imaginário para o simbólico e deste para o real. É no texto "O estádio do espelho como formador da função do eu" (Lacan, 1949) que ele prioriza o registro do imaginário e o momento inaugural da constituição do $e u$, isto é, momento em que o infans, ou seja, aquele que ainda não fala, consegue perceber sua própria imagem no espelho, que é reconhecida pelo outro como verdadeira, o que dá ao bebê uma sensação de unidade e de contorno nítido, fazendo com que a indiferenciação - entre seu corpo e o de sua mãe - que caracterizava seu corpo despedaçado, transforme-se na imagem de um corpo próprio. Conforme observa Jorge (2000, p. 45), contudo, embora o eu seja descrito aqui como essencialmente imaginário, ele náo prescinde do reconhecimento simbólico do Outro do simbólico, encarnado pelo agente materno. Com o estádio do espelho, Lacan demonstra que o imaginário está submetido ao simbólico, portanto. Dado que o eu traz a ilusão de uma unidade corporal, de uma completude imaginária, o sujeito é excêntrico a ele, uma vez que o sujeito é efeito do simbólico, sendo representado de um significante para outro significante. Essa concepção imaginária de corpo, como uma unidade completa, é predominante quando se fala de corpo, tal como se dá nos livros didáticos de LE. 
Conforme Jorge (2000, p. 46),

O imaginário não é da ordem da mera imaginação e esse registro deve ser entendido como o da relação especular, dual, com seus logros e identificaçôes, mas, sobretudo, segundo os desenvolvimentos finais de Lacan, com o advento do sentido. Já o simbólico é da ordem do duplo sentido, e o real, que não se confunde com a realidade, é o não-senso radical, ou, como diz Lacan, o "sentido em branco" [...]. O simbólico é o registro que permite ao falante mediatizar o encontro com o não-senso do real. (grifos do autor)

Dizer que o corpo é uma realidade é dizer que, "como ela, ele é triplo, simbólico, imaginário e real" (Soler, 1989, p. 3). Conforme lembra a autora, no ensino de Lacan uma constante se impóe, que é a distinção entre o organismo, o vivente e o que a língua designa como corpo. Inicialmente, com o estágio do espelho, ele abordou o corpo pela imagem, isto é, para fazer um corpo é preciso um organismo mais uma imagem. O que dá unidade e pertinência e faz o "um" de um corpo é a consistência da forma, a gestalt visual, oposta ao mal-estar, à deiscência do organismo prematuro que a imagem não ordenou. E desde essa prótese do imaginário, que de um organismo fragmentado faz um corpo unificado, concebe-se que essa imagem oferta-se ao amor e toma seu valor libidinal, que é o narcisismo, segundo Freud. A coesão do vivente, como um organismo individualizado, opóe-se entấo ao corpo despedaçado que a linguagem dá ao ser falante, que não tem, além disso, sua unidade senão do "um" do "significante" (Soler, 1989).

No texto Radiofonia, Lacan (1970, p. 406) trata do corpo do simbólico. E no Discurso de Roma (Lacan, 1953) ele já notava: ele é corpo sutil, mas corpo. Em suas palavras:

Volto primeiro ao corpo do simbólico, que convém entender como nenhuma metáfora. Prova disso é que nada senáo ele isola o corpo, a ser tomado no sentido ingênuo, isto é, aquele sobre o qual o ser que nele se apóia não sabe que é a linguagem que lho confere, a tal ponto que ele náo existiria, se não pudesse falar. (Lacan 1970, p. 406)

O primeiro corpo, então, o corpo do simbólico, corpo incorporal, faz o segundo. E por se incorporar nele, ele nos dá um corpo. Daí não ser sem consequências aprender LE, que é transformar-se um pouco em um outro. O simbólico é corpo, como seus elementos são coordenados em 
um sistema de relaçóes internas. Conforme Soler (1989, p. 8), o corpo do simbólico "se apresenta em duplo sentido: ele nos atribui, mas mais exatamente, ele nos fabrica. O Corpo”.

\section{CONSIDERAÇóEs FinAIS}

Cabe, por fim, retomar algumas questóes que aqui foram expostas, destacando alguns aspectos que nos parecem relevantes. No que diz respeito à história singular de cada um, por exemplo, é importante que o professor se atente não só para o que pode haver de sucesso, mas para o que há de impossível no ato de educar, no que há de fracasso, de falta, de incompletude na relação corpo e língua, porque, de tudo que se passa no processo ensino-aprendizagem, por mais atrativos que se forneçam, há muito mais náo controle do que controle sobre o que se passa com cada sujeito, cada aluno, cada professor, em cada situação, cada dia e por aí vai...

Deve-se lembrar, ou não se esquecer, de que somos nada mais que efeitos de linguagem, efeitos do inconsciente, portanto, deixar-se ser afetado pela língua e pelo que a língua provoca, como corpo (materialidade sonora e plástica) e no corpo, em cada aula e em cada aluno. Corpo entendido não somente no que comporta de imaginário, mas no que há de singular mesmo, corpo composto de zonas erógenas ou libidinais que são menos ou mais ativadas ao se aprender uma LE, de um ou de outro modo para cada sujeito em particular, sujeito que se torna um pouco um outro e que sofre, por vezes, exatamente por isso. Afinal, como que se tornar um pouco um outro pode provocar só prazer? Só lúdico? Num grupo de trinta alunos, por exemplo, quem está disposto a isso? Quem dá conta disso? Que metodologia vai "funcionar" para um e não para outro?

Pode-se perguntar, porém, em contraponto: o que deve fazer o professor, então? Deve, evidentemente, cumprir seu papel de ensinar. Fazer o que considera ser o melhor, das melhores maneiras, como sempre foi dito. Mas sabendo que não há garantias. Não há como garantir que o aluno seja capturado pela língua. Isso simplesmente acontece ou não acontece. Apenas em um tempo posterior é que resultados poderão ser observados. $\mathrm{E}$ essa captura é da ordem do inconsciente. É de cada sujeito.

A língua não é meramente um instrumento de comunicação e o corpo não é só um corpo imaginário que sabe como dizer isso ou aquilo em uma LE. O corpo é real, simbólico e imaginário, o corpo é efeito do real da língua, 
isto é, do que dela há de irrepresentável, que é da ordem do puro som, da voz, do prazer do jogo sem sentido, do jogo poético, musical, plástico. O corpo é efeito do entrelaçamento desses três registros e esses três registros compõem as presenças também reais disso que é um encontro - e um desencontro -, sempre singular e jamais repetível, entre professor e aluno, ou entre aluno e aluno, ou entre um aluno e o próprio aluno, como sujeito dividido que é. Encontro que, em se tratando de uma LE, pode soar especialmente estranho, no entanto, não menos estranho do que o encontro - e o confronto - com a obrigação de tornar-se um sujeito falante, ao se "adquirir" a língua materna.

Tudo o que o professor diz ou silencia, tudo o que faz em sala de aula produz efeitos. E principalmente o que se faz e o que não se sabe que está fazendo e que, no entanto, é passado pela voz, pelo olhar, por uma escuta, uma dada entonaçáo, efeitos que dizem respeito ao real do corpo e para os quais não se tem nome, porque bordejam o irrepresentável, mas que produzem efeitos.

Vale destacar ainda o papel importante da sublimação, o papel fundamental da arte em sala de aula, do poético, da música, do jogo, do humor e do riso. O poético, conforme observado em outro momento (Murce, 2003), por se sustentar no jogo de significantes e por trabalhar com o corpo da expressão, o corpo verbal, o que a palavra tem de coisa e da Coisa, permite, por isso mesmo, a possibilidade do novo, de rupturas, de estranhamento, de espanto, de exploração dos sons de uma língua no que esta, em sua ordem (lei) e (diz!)ordem (desejo), autoriza e desautoriza em termos de jogos metafóricos e metonímicos. Por se produzir no jogo de sons e diferenças, o poético permite que se suspenda o nível do sentido (imaginário), do duplo sentido (simbólico), para se trabalhar no nível do significante e da letra (real) que, por náo se constituir um sentido preestabelecido, afeta o sujeito em sua materialidade sonora, singularmente, no modo como ressoa no corpo. É somente pela via do corpo e no corpo que algo do novo pode afetar o sujeito, convocá-lo, mobilizando-o. O novo (estranho) ressoa no corpo, fazendo sentido ao sujeito, ainda que não se compreenda esse sentido, arrebatando o sujeito, mobilizando-o. A arte (o poético) bordeja o vazio, o irrepresentável, a Coisa, daí produzindo o novo.

Importa trabalhar com o texto em sala de aula não somente no que concerne ao registro do sentido (imaginário), mas no que o texto possui de puro jogo com o significante, com a pura diferença, podendo-se fruir o que esse texto comporta de material plástico, sonoro, a ser manipulado, 
despertando o leitor para um nível que ultrapassa o nível do sentido. Daí a prática teatral poder ser interessante, a memorização e a recitação de textos poéticos, a escrita de textos-colagem, permitindo-se que o aluno viva a língua e que seja surpreendido pela língua, capturado, singularmente.

\section{REFERÊNCIAS}

AZENHA, C. A. C. Professor, não vês que estou queimando? Revista Solta a Voz, Goiânia, Cegraf/UFG, v. 18, n. 1, p. 29-39, 2007.

CAMARGO, A. C. C. S. Educar: Uma questão metodológica? Proposiçóes psicanalíticas sobre o ensinar e o aprender. Petrópolis: Vozes, 2006.

FINGERMANN, D. Os passadores do pior - Beckett, Blanchot, Duras: Travessias. In: FINGERMANN, D.; DIAS, M. M. Por causa do pior. Sáo Paulo: Iluminuras, 2005. p. 93-105.

FREIRE, S. M. Glossolalias: ficção, semblante, utopia. 2007. Tese (Doutorado em Linguística) - Instituto de Estudos da Linguagem, Universidade Estadual de Campinas, Campinas, São Paulo, 2007.

FREUD, S. Os chistes e sua relação com o inconsciente (1905). In:

Obras psicológicas completas de Sigmund Freud. v. VIII. Rio de Janeiro: Imago, 1996.

—. O estranho (1919). In: — Obras psicológicas completas de Sigmund Freud. v. XVII. Rio de Janeiro: Imago, 1996.

GARCIA-ROZA, L. A. O mal radical em Freud. Rio de Janeiro: Jorge Zahar, 1990.

JORGE, M. A. C. Fundamentos da psicanálise: de Freud a Lacan. Rio de Janeiro: Jorge Zahar, 2000.

LACAN, J. O estádio do espelho como formação do eu (1949). In:

Escritos. Rio de Janeiro: Jorge Zahar, 1998. p. 96-103.

—. Função e campo da fala e da linguagem em psicanálise (1953). In:

—. Escritos. Rio de Janeiro: Jorge Zahar, 1998. p.238-324.

$1974 / 5$.

O Seminário, livro 22 - RSI. Ornicar? v. 5. Paris: Le Graphe, 
LACAN, J. Radiofonia (1970). In: . Outros escritos. Rio de Janeiro: Jorge Zahar, 1998. p. 400-447.

LAJONQUIÈRE, L. Infância e ilusão (psico)pedagógica: escritos de psicanálise e educação. Petrópolis: Editora vozes, 1999.

MORAES, M. R. S. Maternalestrangeira: o que Freud fez da língua. 1999. Tese (Doutorado em Linguística) - Instituto de Estudos da Linguagem, Universidade Estadual de Campinas, Campinas, São Paulo, 1999.

MURCE, N. Da escritura ao corpo e do corpo à escritura. Revista Solta a Voz, Goiânia, Cegraf/UFG, v. 14, n. 2, p. 67-74, 2003.

POMMIER, G. Naissance et renaissance de l'ecriture. 2ème triage. Paris: PUF, 2004.

REVUZ, C. A língua estrangeira entre o desejo de um outro lugar e o risco do exílio. Trad. de S. Serrani-Infante. In: SIGNORINI, I. (Org.). Lingua(gem) e identidade. Campinas: Mercado de Letras; São Paulo: Fapesp, 1998. p. 213-230.

SOLER, C. O corpo no ensino de Jacques Lacan. Trad. náo publicada de M. Marinho, F. Fontenelle e L.E. Rosa. Belo Horizonte: Papéis do Simpósio, 1989.

VERAS, V. O e(x)trangeiro na língua materna: (não) desejar as coisas alheias. Revista Solta a Voz, Goiânia, Cegraf/UFG, v. 19, n. 1, p. 111-124, 2008.

VOLTOLINI, R. O discurso do capitalista, a psicanálise e a educação. In: LEITE, N.; AIRES, S., VERAS, V. (Orgs.). Linguagem e gozo. Campinas: Mercado de Letras, 2007. p. 197-212.

VORCARO, A. O que se quer quando se quer ensinar? Texto apresentado no VII Colóquio Linguagem e Educação, 2008. Mimeo.

Recebido em: 18 out. 2008

Aceito em: 15 fev. 2009 